\title{
CONFIGURING CENTER-PERIPHERY RELATIONS: RELATIONAL LEGACY IN THE OVER-CENTRALIZED STATE
}

\author{
Elena TRUBINA \\ Institute of Social and Political Sciences, Philosophy Department, Ural Federal University, \\ 51 Lenina Ave., 620083 Ekaterinburg, Russia \\ E-mail:elena.trubina@gmail.com
}

Received 18 November 2014; accepted 12 March 2015

\begin{abstract}
This essay explores the idea of relational legacy in connection to the interconnected group of central and provincial cities. The concept is applied to concrete explorations of the relationship between the cities. We explore the idea through the emergence of discourses on nation, interurban differences and various conceptions of belonging. We find that the relational dynamics of urban space has been actively constructed by the media. It is concluded that existing conceptions of interurban relations need to take account of the contradictory dynamics behind the urbanites' perception of cities. We also need to contend with manifestations of "state racism" which appear to achieve a greater prominence.
\end{abstract}

Keywords: globalization, center, periphery, relational legacy, overcentralization, mass-media, belonging.

\section{Introduction}

Although globalisation introduced new relations between cities previously separated by geographical distance, in many regards it reproduces centre-periphery relations globally and within many countries (Appadurai 1986; Keil 1994; Griswold, Engelstad 1998). Urban systems are comprised from the central and peripheral locations and their understanding often depends on "the simplifying assumptions of central agents and agencies when they look from the centre towards the periphery" (Marvin, May 2003: 215). Policy-makers' interpretations of cities are similar to national urban systems research which analyzed city/ state relations in 1970-1980s (Weir 1996). The complex dynamic of transnational and intranational networks that coexist in the urban environments were largely ignored by this school which investigated the progress of "national urban hierarchies" seeking to capture them as "concrete geographical manifestations of 'national economies" (Taylor 2007: 134). Whether at central or local level, the ideas of hierarchy and subordination have been pivotal in understanding interurban relationship while all cities in a particular country are evaluated and perceived through takenfor-granted assumptions, namely, they are placed into the container of the national territory and national economy. In urban studies as well as in cultural and social geography, this understanding of space is actively contested. A substantial body of literature is based on the assumption that the "container" metaphor in the traditional theoretical rendering of historical transformations, including nationalism and globalisation is outdated (Beck 2002; Turner 2002; Delanty, Rumford 2005). This metaphor implies that the world as well as the smaller scales (the continents, the countries, and the regions) are easily combined in a nesteddoll manner, as territorial bunkers of power, and as inactive, permanently given spaces. Ascendance of the "container" perspective often results in what Ulrich Beck described as "methodological nationalism": an insistence on interpreting every social phenomenon through the national gaze (Beck 2002) or imagining "the global social economy" as "plethora of containers - nation-states - within which float a number of smaller containers, the cities" (Smith 2002: 431). It is instead suggested that space is not just a container but that many processes and relations (including the ones which extend far beyond actual physical location whether these are linked to production, consumption, or 
everyday life) coalesce to make and change it (Lefebvre 1991; Massey 1994). A similar argument has been developed by historians, literary scholars, philosophers and other proponents of cosmopolitanism as a new research agenda for the social sciences in the twenty-first century. Cosmopolitanism is defined here as "a process of 'internal globalisation' through which global concerns become part of local experiences of an increasing number of people". Global media representations, the scholars suggest, "create new cosmopolitan memories, providing new epistemological vantage points, and emerging moral-political interdependencies" (Levy, Sznaider 2006: 97). This relational perspective is often, explicitly or implicitly, put in opposition to an earlier understanding of space which has instead a strong focus on the form-giving and meaning-giving capacity of a nation or a city which shape the otherwise chaotic complex of temporary links which people generally form (Castells 2002).

In Eastern Europe and Russia, there are many trends that inhibit people's interest towards connections with other places, cities and countries. Propaganda of "the Russian Version of the 'Special Path' (Merridale 2003) prompts numerous online discussions about things 'specifically Russian”. In cities, imperial myths become popular, mapping themselves by way of geopolitical imaginaries. For a critical urban researcher, the challenge is to see, how in city inhabitants' perception, propagated isolationist sentiments coexist with one's identity, history and sense of place. "One and only one national container society" (Beck 2002: 25), that is the territorial confines of the nation-state, while constantly discussed by the media, make is difficult to sustain a dialogue between the different perspectives regarding the relationship between globalisation and national belonging. Discursive aspects of commitment, loyalty and common purpose are now predominantly discussed so that they have rather exclusive than inclusive effects (Crowley 1999). Notions of center and periphery are often at the heart of popular and political discussions about cities and often taken to involve subjective dimensions of snobbism, resentment and disappointment. By reifying the nation-state as the superior - if not exclusive - container for a pomp and breast-beating, the state propaganda tries to camouflage the fact that the profit of the corrupt center means the impoverishment of the periphery. The wishful images that the federal government constructs through nationalist narratives makes the nation the most important of all the spatial "dolls" or "containers", it is the nation that definitely comes forward. One dimension of this complex dynamic expresses itself in the discourses by which economic interests of the country's ruling circles are cleared away by active use of phrases like "national influence", "a country's commanding position", etc.

Simultaneously, a qualitative shift in people's perceptions and emotions related to center-periphery relations takes place. There is a complex dynamic of re-centralization (which is the most important characteristic of the country's political life) and de-centralization (which is particularly obvious when it comes to people's everyday concerns). All this develops in the wider context of Russia's entering the global circuit of finance, information, and image production. Importantly, the increased exposure of Russian urbanites to the major components of globalization, namely, the flux of people and the flow of commodities and images, has been combined with their cities remaining embedded in the highly centralized national urban hierarchy. What role then the urban identities play in the reproduction of social exclusion and how the state's responsibilities and policies are perceived by people and justified by creative entrepreneurs? In this article, I'll try to make sense of the configuring of centre-periphery urban relations in Russia by addressing three issues: (1) the changing center-periphery relations, (2) the "technologies of affect" that are at work here and, (3) as a way to reflect on the qualitative shift in people's perceptions and emotions regarding Moscow and their own cities, the experiences of foreign travel and spatial freedom. This is work-in-progress. It is part of a larger project I am currently working on dealing with mobility and cosmopolitanism in Russian cities. My research has been on the growing heterogeneity of the urban mobilities characteristic of large Russian cities as reflected in the ways different communities of people map and describe their activities. In terms of the empirical material I analyze, this article is based on one TV talk show and in-depth interviews with 15 informants based in Ekaterinburg and Moscow with whom I discussed their travel abroad and across Russia. I conducted interviews with informants, selected by combining a snowball progression that followed "natural" networks, and a systematic sampling that diversified travelers along lines of social profile, frequency, and remoteness of travel. Rich and productive data were also derived from engaging in talks with passengers in airport lounges and on planes. My additional field strategy was thus to use these informal interactions to collect "unsolicited accounts" (Hammersley, Atkinson 2003: 99-101) in which people's moods, biases, and subjective identifications are conveyed in a less controlled a manner. In addition to this, the analysis draws on documentary and media materials. 


\section{Changing center-periphery configurations: relational legacy}

Two narratives, one on the socialism-to-capitalism transition and the other on globalization, seem to be unevenly at work when it comes to conceptually framing the development of post-socialist cities. In spite of the sense of inevitability that many accounts on globalization convey, post-socialist cities are seldom portrayed in the context of globalization. This is unfortunate. Geographers, reflecting upon the challenges that cities face in a global age, criticize the treatment of spaces and places as bounded areas. They call for a "non-containerized" and relational approach to cities and try to promote a view of cities as lacking prescribed boundaries. There is a sense, however, in which particular views persist in the formulation of people's perception of each other and of the paradoxes, exclusions, and segmentations that have always been associated with city form and urban organization. These views are based on heavily investing in drawing the boundaries between those who belong to Moscow and the ones who don't. The "relational" part of the concept I introduce here is meant to grasp the ideas related to both the persistently reproduced and the changing hierarchy of cities. The "legacy" aspect of the relational legacy I explore has to do with the fact that the Soviet state was distinctive among modern states. It thoroughly institutionalized a hierarchy of cities, built on the propiska system (both a residential permit and the residential registration of a person) and the designation of some towns as having strategic significance and benefiting from special provisioning.

Globalization is thought to be accompanied by the de-centralization of the governance as sub national and transnational power holders emerge. One of the difficulties in thinking about the new scalar dynamic of post-Soviet cities is that in Russia there is a trend toward extreme re-centralization that, in times of crisis, combines with the state's shaking off all expenditures that do not promise immediate benefits. This recentralization was based on the redistribution of regional finances in favor of Moscow and of municipal ones in favor of the regions. Today the global flows and variously directed currents of finances, ideas, and goods also tend to "crystallize" predominantly in Moscow by virtue of its being the top or the main site of the current Russian "vertical power" political system. There is a sense in which many urban tendencies in Russia could be better described through combining the globalization argument with the one that takes existing hierarchies into account. In other words, it makes sense to look at the unfolding tendencies both through the lenses of multiplicity of scales characteristic of globalization and the levels of the state hie- rarchy when the highest levels direct the distribution of resources and enjoy the greatest benefits.

My argument in the article is that globalization discourse gets appropriated by various societal and political forces and that the appropriation of discourse is combined with fundamental changes in people's views and practices. These become enriched by the wider circulation of ideas and images, new points of reference, and processes of migration and mobility. I conceive of globalization-related opportunities as a facilitating factor that determines the degree to which these decentralizing tendencies may be related to people's mental mapping of their cities and their country vis-à-vis the whole world. On the other hand, there still is clearly one capital city. Its privileges are resented by those it deems "provincial", and it stimulates acute hostility which marks the mutual perceptions of the inhabitants of Moscow and those residing elsewhere. Conceptually, I am inspired here in part by Nigel Thrift's chapter, "But Malice Aforethought" in his "Non-Representational Theory" (2007). Here, Thrift speaks about the contemporary Western urbanunconsciousness comprised - and here in his trademark style - from "sedimented cultural-cum-biological-cum technological shortcuts which produce particular kinds of interactional intelligence" (Thrift 2007). Part of this intelligence is what Thrift refers to as "dark feelings", and the chapter is generally about the reasons why misanthropy and "ubiquity of aggression" is so little thought about by those who write on cities. If Thrift, however, seems to be mostly concerned by technologies of affect that are at work in the cities, my interest is toward the love-hate relationship between cities. The case I try to build is about the relations between Moscow and the provinces, in particular.

Moscow, in some people's perceptions, figures as the embodiment of legitimacy, a site of domination, and a field of endless opportunities which cause anguish in those who haven't moved there (what if they miss the chance of their life?) But for others, there is a growing sense that the life style that Moscow encourages is not the only one possible. As one interviewee claimed, "Moscow is the concentration of the material and administrative resources, thus if you are ambitious, you should live there. But you obtain your connections at a price. It is a nasty city in terms of cost of living, the time you spend to get to places, and the wilderness, too, is far away from the city. Sure, you can shop endlessly there. If your priority is money, this is an excellent place to live but when it comes to quality of life, Moscow loses in the competition with other cities". The capital thus becomes the empirical reference point for those who are increasingly dissatisfied with the lack of diversity when it comes to life values, with money being what most people value. A prominent, Perm'-based Russian 
writer Alexandr Ivanov whose historical novels, such as Heart of Parma, focus on the Russian colonization of the Urals, is correct to claim that "There have been the attempts to impose on Russia a single way of living. Today it is the Moscow one. One shouldn't follow it." (Milchin 2010).

\section{Post-Soviet neoliberalism: "state racism" and modulating of affect}

One can argue that "a single way of living", "a Moscow living" a Russian writer talks about is, in a sense, a post-Soviet version of neoliberalism, that is a model of the "economy" within which low-paid employment has flourished while a rolling back of state welfare and significant state investment in the financial and business services sector have all helped hasten processes of deindustrialization while fostering the consumer boom that has underpinned the shift to service employment associated with the rise of "flexible" labour market (Brenner, Theodore 2002). What I want to emphasize is that neoliberal relationship of governance and economy is such that together with the promotion of market forces comes, what Michele Foucault termed "state racism", namely, the "processing" of the populations in the way which encourages "survival of the fittest" ideology and modulates their affect (Foucault 1997: 254-263). Defense of social Darwinism is inevitable in the current era of the marketized uptake of the old Russian tradition of distributing resources within a small group of the elite which is equivalent to a current "zero" social mobility, to a careful shielding of the borders separating those who have access to oil and gas revenues and other assets, and those who do not. Under the conditions of globalization, the government, albeit cynically, is conducting the only promising "entrepreneurial" strategy, namely, offering an opportunity to its inner circle to accumulate personal assets by selling abroad any resources they can get hold of. This prompts a great deal of both competition for attractive jobs (many of which are concentrated in Moscow) and passive adaptation, particularly in provincial Russia. The traces of economic decline, physical decay, and a sense of doom are particularly visible in the small and middle-size towns where the living condition make questionable even "the devotion of the workers to a life of ceaseless toil for a mere subsistence wage", (Huxley 1989: 83). Many of the towns are subjected to the consequences of underinvestment, while manufacturing employment is rapidly decreasing, and there is no organized activity to improve the condition of disadvantaged people in society. The moods of endurance and depression, conservatism and quiet despair are often mentioned in the conversations. They become combined with various geopolitical fantasies: the more "empty" and short of meaning one's life becomes, the more significant thinking in terms of state territories becomes. The ideas of "the 'temporary' nature of all state boundaries, since subject to the ongoing struggle for space between competing state actors", not dissimilar to the ones developed in the end of nineteen century by Ratzel, are popular (Minca 2006: 395). Just like the idea of the strong center and its charismatic leader took hold in many minds, the idea that the big state like Russia is entitled to expand at the expense of the smaller state doesn't seem questionable to many.

At the same time, provincial inhabitants' perceptions of Muscovites are marked by their own poverty and humiliation. Local authorities appear indifferent to this poverty while the inhabitants of small towns are left with little leverage for demanding better working conditions. Locals' dread is often associated with the loss of self-esteem experienced by virtue of these macroeconomic and social processes. Russians see themselves as the unjustly deprived of the things and conditions they feel entitled to, while those living in the capitals seem unfairly advantaged and empowered. This politically structured set of emotions, begetted by the media, produces locals' enmity towards the luckier ones. They often consider as unjustly more privileged both the citizens of the capitals and those residing abroad. One is reminded here that Brian Massumi uses the term "relationality" to account for the dynamic underlying what he terms "the Political Economy of Belonging” (1997). In a similar vein, Tiziana Terranova, like so many other cultural critics, argues that digitized tele-technologies are fundamental to the constitution of the publics of populations because these technologies are most able to produce a public through the provisional capture and dissemination of affect (2007: 140). I now turn to one example of "disseminating of affect" by means of tele-technologies by briefly considering one episode (or release) of the talk-show, "NTV-shniki", the one devoted to Moscow-provincial relations. It was titled "Zamkadyshi" (Zamkadyshi 2010). This is not a widely used term. It is a diminutive and pejorative term, derived from the abbreviation MKAD, which is the road ringing Moscow. It refers to those who live beyond the ring: not in Moscow, in the boonies. This part of the country's population, according to this view, begins just beyond the ring road and expands throughout the rest of the country. This show was surely outrageous, but it was clever way of channeling people's emotions in a direction that not only suits the authorities but has a peculiar importance for people on both sides of this imaginary divide, the ring road. The host of the show cited a cynical proposition that the country doesn't need that many people because anyway 
its life, really, rotates around the oil pipe. The proposition and the show itself seem to me a sheer expression of the state racism that Foucault speaks about. In analyzing this show, I find a strange discrepancy. Those engaged in globalization discourse often claim that the problems of underdevelopment don't come from the global economy itself. Rather, they lie mainly in the societies themselves - in authoritarian government, corruption, conflict, over-regulation, and the low level of emancipation of women (see, for instance, Giddens (2000: 129). But these very arguments get appropriated by the nationalist ideologists working for the authoritarian governments this argument renders responsible for underdevelopment! This is surely very ironic. The argument posited in the framework of globalization discourse is that insofar as the world is still divided into core and periphery, this has little to do with the world economy and much to do with the bad policies of the peripheral states. The hierarchical core-periphery divide can therefore be overcome through embracing the world economy (this is a neoliberal version of modernization theory). When appropriated, the argument is that in one country, Russia (which is also divided into the core and the periphery), all those residing beyond the ring road are poor because of their bad habits, constant drunkenness, and general inability to engage in something useful. Moscow is depicted as the only European space, surrounded by sheer wilderness. Its inhabitants are young, advanced, and hardworking; the inhabitants of provinces are drunken and passive.

Last summer (August 2010), as I left the commuter train from Domodedovo airport, I overheard a young woman ask her party, "How do the people live here?" Moscow was struggling with the unprecedented heat and the dense clouds of smog coming from the peat swamp fires. I watched friends trying to reanimate their choking air conditioners after spending long hours in their overheated offices. Everybody seemed exhausted in the sweltering city: underground workers, salespersons, and pedestrians. The country's capital had turned into a trap. Among the passengers being stuck at the sultry Moscow airports, many were just changing planes. Those who looked forward to their vacations or who had taken some days off to get out of this disaster had to wait long hours at the airports since many planes were diverted and many flights were delayed or cancelled. The more compassion I felt toward the Muscovites who had to endure weeks of intense heat and smoke, the sadder and more disturbing it was to hear here and there, outside of Moscow, the claims of ordinary people, which were hardly sympathetic. Rather, they ranged from, "They had it all coming," to "I simply can't feel sorry for them since they have been enjoying all these privileges for decades!" Although, as a rule, people are aware that natural disasters are different from moral evils by virtue of their randomness, the fires on the outskirts of Moscow were perceived by many resentfully, with malicious pleasure, as a punishment the city deserved for being vicious, hollow, exploitative, and indifferent to the well-being of the country as a whole. More generally, the difficult Moscow summer of 2010 symbolized the distance between the notorious line of a Chekhov heroine, "Moskva, Moskve, Moskvoi" and a new, much more complicated attitude toward Moscow, living in Moscow, and the Muscovites, which began emerging during the last decade.

\section{Moscow and provincial towns: relational legacy}

Two narratives, the one on the socialism-to-capitalism transition and the other on globalization, seem to be unevenly at work when it comes to conceptually framing the development of post-socialist cities. In spite of the sense of inevitability that many accounts on globalization convey, post-socialist cities are seldom portrayed in the context of globalization. There are only a few explicit attempts to combine the two, as in Georgy Andrusz's article on post-socialist cities (2001: 1837), Olga Shevchenko's and Yakov Schukin's account of everyday life in present-day Moscow (2004: 89-111), Diana R. Blank's ethnographic analysis of Chelnochovsk-na-Dniestre, a border town on the southwester border of Ukraine (2004: 349-378), and the monograph that resulted from the Bauhaus Kolleg 2003 project "Transit Spaces" (Bittner et al. 2006). If Andrusz believes that attempts by a city to develop a tourist industry, the prominence of a criminal economy, private banks, and numerous shopping malls can be thought of as expressions of globalization, Shevchenko and Schukin claim that it makes sense then to differentiate among economic and ideational globalization processes, to talk about asymmetric globalization, and to look at how this asymmetry can be traced in "specific ways in which [...] differently positioned actors experience globalization in their everyday life" (90). While Blank interestingly shows how global flows amplified the importance of place for many people and turned most places we know today into "separately-but-equally globalized sites" (355), the sociologists, architects, and designers have mapped their field trip along the "transit spaces," (i.e., the transport corridor that stretches between Berlin and Moscow) and have shown the controversies underlying the eastward traffic of goods and images. Part of these controversies has to do with "over-centralization" of the country which reduces citizens' capacity to act independently. Reflecting on the impact of global chan- 
ges on the existing social structures in Russia and abroad, people believe that many new lifestyle changes and opportunities were made possible by globalization (elsewhere, I have shown that the words "world', and "openness to the world" appeare in the interviews in exactly lifestyle context (Trubina 2012). In contrast, in the discussions of job opportunities the nationallybounded relationships between "us" versus "them", that is, "the State versus the rest" predominated.

The urbanists do not count Russia among the "monocephalic" countries in which up to 20 percent of the urban population reside in one city. They claim, for instance, that "the largest countries, China, India, the United States, Russia, and Brazil, are characterized by urban multipolarity" (Dogan 2004: 350). But, the dominance of Moscow in the economic, administrative, political, and cultural life of the country is truly remarkable. In the conversations and interviews that I conducted, everyone commented on the immense concentration of finances and wealth in the capital. The exact percentage people mentioned did vary from 70 to 95 percent, but the point was always the same: Moscow concentrates the highest share of the country's finances so it is understandable that most opportunities can be found there, closer to the source. The other point that everybody wanted to make sure I understood is that the network of communication converges to the capital the railways and airline routes radiate in all directions from Moscow. It was for decades that people travelling in any direction were obliged to pass through Moscow. When asked, "Aren't all major world airports located in or near the major cities everywhere?" my interviewees would agree and yet some seemed to have taken it rather personally that air traffic between big cities is much more intense than between smaller ones. The wide discrepancies among cities in terms of available resources and opportunities make people particularly sensitive to the negative consequences of the country's high centralization and economic restructurization. Their subjective identifications and the ways they express their aspirations and belongings are intertwined with their reflections on the field of power.

Very varied and unevenly distributed, two opposed tendencies take place in Russia, similar to what is going on everywhere. On the one hand is the exponential growth of capitals and global cities. On the other hand, there is a tendency which has been described as "shrinking cities" (Oswalt 2005), ones that lose their population. Many Russian regional cities have faced reduced economic vitality resulting from the consequences of de-industrialization: the disappearance of manufacturing jobs, the hollowing out of the industry, and a declining population. These macroeconomic tendencies have their emotional equivalent.
It is enough to leave any capital or global city and find oneself in a regional town to be struck by the contrast between the vibrancy and energy of the former and comparative dullness of the latter. In this regard, it is not important where this town is located: whether it is Sheffield in England, Worcester in Massachusetts, or Ivanovo in Russia. Nearly any city nowadays not only experiences dramatic transformations related to deindustrialization, but it experiences its own version of the love-hate attitude towards a capital or a global city.

When it comes to an intellectual assessment of these processes in Russia, "the provinces" and provinciality, which traditionally were discussed by the intellectuals as embodiments of purity, altruism, and patriarchal values, have been described today through the lens of economic analysis and with use of "thick" descriptions (Orehovski 2006; Karachurina 2006). At the same time, the hierarchical placement of Russian cities along an imagined scale of spiritual values takes place in recent works as well. The towns less touched by modernization and industrialization seem to observers a more "pure" embodiment of a "proper", "spiritual" provinciality than their heavily industrialized counterparts. For instance, the editor of the thematic issue of "Otechestvennye Sapiski", devoted to provinces, argues as follows:

The province can be poor, stagnated, and hungry; it can be endlessly far from where raw minerals, universities, plants and steam ships are located. It nevertheless remains unmistakably identifiable - by indelible spirit of the Russian literature, by the charming landscapes reminiscent to the ones painted by Isaak Levitan, by scrapping by and yet always filled theaters, by miraculously intact libraries and lovingly cared about local historical museums, by the humble pride of the provincials, by the fact that life, calmly and stoically, goes on there. Torzhok is the province while Chelyabinsk is not. It is impossible to prove but absolutely understandable (Otechestvennye Zapiski 2006).

Many towns thus "didn't make it" into the range of "proper" provincial cities, most probably because they lack this provincial "poetry." Intercity relations, particularly the ones between the capital or the big city and the smaller ones, have always been the subject of uneasy discussions. To the sheer wealth of opportunities, vibrancy, and diversity that a capital city can offer, one should add the discursive weight of what has been written about Paris, London, and their counterparts. It might seem that everyday life is something that cities, large and small, have in common, but this is not the case, either. Reflecting on the famous urbanists' work on urban everyday life, Nigel Thrift notes that, "The cities that these writers consider are doubly centered. They are nearly all important urban centers - pivots of the world and, more than that, their writing nearly all concerns 
the central cores of such cities. It is difficult to think of the sitiationists in Stevenage, de Certeau in Catford, or Lefebvre in Lewisham - though it is a beguiling prospect" (2003: 399). It is equally difficult to think about the prominent Russian urbanist Vyacheslav Glazychev residing in Tver or a geographer Vladimir Kagansky living in Irkutsk. However, the provincial Russia (glubinnaya Rossia) comprises the subject of Glazychev's numerous expeditions and action research (Glazychev 2000) and Kagansky's social geography (2001). The knowledge of life in the provinces allows them to position themselves in opposition to those who do not want to know anything about the rest of Russia. The country's capital figures in their work, not as a proper or exciting place, but as a "non-city" (Glazychev 2000: 160) or as a "city without the inhabitants" (Kagansky 2001: 391). The ambivalence of the co-existence of idealized or optimistic images of the provinces with critical renderings of Moscow as a city produced by the urbanists reverberates with the popular sentiment towards provincial life vs. urban life in Moscow.

A British anthropologist Anne White describes in her book, Small-Town Russia, the controversial attitudes of many inhabitants toward Moscow and outlines four varieties of them: Moscow is perceived as being (1) different (when people call the capital "a different state" or "another continent" and believe that "Moscow lives its own life"), (2) indifferent ("The political elite don't know anything about what goes on at the grassroots"), (3) hostile/greedy ("Moscow was never on good terms with the provinces and always exploited them", "People hate Moscow because it sucks up all the resources", "The provinces were always left to stew in their own juice"), and (4) immoral ("People are more moral in small towns than in Moscow and Petersburg", "Russia will be resurrected thanks to the provinces, where some spirituality still resides", "The best people are in the provinces") (2004: 200). There is a sense in which provincial people are increasingly stripped of the identities that their immediate milieu delineated, sustained, and reproduced; they thus need a devilish "Other" of the capital to better understand who they are and, more important, to compensate for a sense of the limited opportunities that their way of living constantly reproduces and installs in them. On the other hand, the urge to aggressively delineate who is a proper Muscovite is characteristic for many spontaneous conversations and public discussions. Muscovites, too, tend to identify "success" with the city of their choice: when their city is criticized, they often take it as questioning their life strategy. Moscow encourages a strong identification. The exchanges (often angry) between the "real" Muscovites, "not-quite" Muscovites, aspiring Muscovites, former Muscovites, et al., in my view, betray an acute anxiety behind one's decision to move to, or to stay in, Moscow. The Russian capital city, on the one hand, gives one a sense of legitimacy, which Pierre Bourdieu describes as "the fact of feeling justified in being (what one is) or being what it is right to be" (1984: 228). On the other hand, increasingly it takes its toll: people spend hours in traffic jams. Public discussions and interviews problematize Arjun Appadurai's argument that globalization means, among many things, deterritorialization (2003: 37-39). For him, borders either disappear or symbolize flows (2003: 46). In contrast, the inhabitants of the overgrown, monstrous city long for strict borders and dismissively talk about zamkadyshi (i.e. those based behind Moscow's Ring Road).

The relational legacy is thus premised on two facts. First, during Soviet and post-Soviet times, Moscow came to symbolize the successful life, one's career, an object of one's aspirations, and the most desirable city in terms of social mobility. Even if people have a chance to see other places, Moscow, by virtue of its being for so long the magnet of their imagination and a privileged site, remains a major reference point. Second, Moscow is rapidly changing because of its being a migration hub and the destination of geographical mobility (which, in turn, is caused by the fact that for many people it still embodies a prospect of better life) and doesn't seem to be able to cope with all current challenges. "Relational legacy" is the term I first introduced in the paper at the 2011 AAG Annual conference in Seattle and at two more conferences this year. I understand by relational legacy the cumulative impact on the urban inhabitants that the history of controversial emotions and attitudes which develop over a period of time has.

Doreen Massey demonstrates the degree to which the attractiveness of London is built on its relations with other places. The UK regions supply skilled young people, and the remote regions of Africa are a source of oil revenues (Massey 2005, 2007). If in the British Marxist geographical discourse, the dependence of the capital on the exploitation of other places is exposed and criticized, in Russia the intellectual rendering of similar relations is often marked by ambivalence. In the words of one interviewee: "Moscow, everybody knows, is a vacuum cleaner: it sucks people up, chews them and it remains unpredictable whether one succeeds the way she wants to." Another says: "I'd be happy to temporarily work in some other country because there is no such striking difference between the capital and periphery". When asked what this difference is, people, as a rule, refer to the difference in wages, the highest ones available only in Moscow. The novel inequalities and exploitations that Moscow came to both implement and embody express themselves in many dialogues 
between Muscovites and people residing elsewhere. A mutual and deep-seated hostility is displayed. The cultural representations provide a source for it. I, however, wish to argue that the habitually drawn picture of the power differential between a fast growing country's center and its backward periphery, which results in hostility, should be problematized by a contextualized analysis of the mobility practices and attitudes of the large cities' inhabitants.

To sum up the conducted interviews, Moscow, in some people's perceptions, figures as the embodiment of legitimacy, a site of domination, and a field of endless opportunities which cause anguish in those who haven't moved there (what if they miss the chance of their life?) But for others, there is a growing sense that the life style that Moscow encourages is not the only one possible. As one interviewee claimed, "Moscow is the concentration of the material and administrative resources, thus if you are ambitious, you should live there. But you obtain your connections at a price. It is a nasty city in terms of cost of living, the time you spend to get to places, and the wilderness, too, is far away from the city. Sure, you can shop endlessly there. [...] If your priority is money, this is an excellent place to live but when it comes to quality of life, Moscow loses in the competition with other cities." The capital thus becomes the empirical reference point for those who are increasingly dissatisfied with the lack of diversity when it comes to life values, with money being what most people value.

\section{Conclusions}

In this paper, I employ the notion of relational legacy to argue that although the binaries, core-periphery and center-margins, are continually reproduced in the reflections of the inhabitants of Russian cities on their style of living, the broadening of their experience that globalization has brought leads to problematizing Moscow's place in one's hierarchy of values, aspirations, and desirable cities. Thus, in Russia in the 21st century, the opposition of center-periphery has been both reproduced and reconfigured. Although cheap airfare and the increased availability of goods bought via the Internet decreases the importance of Moscow both as the travel hub and as the place where all "deficit" used to be concentrated, the changes which globalization has brought have to be seen together with an uneasy emotional dynamic underlying the relations between Moscow and the provinces. The general findings from these in-depth interviews were that (1) there are strong links between the intensity and scope of one's travels and one's positioning oneself in the city (as well as a general assessment of a city as great/moderate, good to live in/posing a lot of problems, etc.); (2) having a chance to evaluate how things are in distant places compared to "back home" makes people's vision more stereoscopic - their judgments are informed by all sorts of geographic and social differences; (3) the meaning that their travel have for them is related to their positioning themselves in society, thus their understanding of geographical mobility is strongly connected to social mobility - being well-travelled serves as one's class-marker and a major component of a high level of cultural capital. The new experiences that increased geographical mobility has made possible prompt people to reconsider their attitude towards the city that once reigned supreme in their imagination. Perhaps, exactly because Moscow reigned for so long, it is now under such scrutiny. The complicated intercity relations affect people's understanding of social mobility and difference, while their geographic mobility makes them relatively immune to the cultural pressure, to the Das Man's voice saying that it is only when one is based in Moscow than one is successful and worthy of something. In the perception of my informants, Moscow has lost part of its charisma. The inferiority complex toward those living in Moscow that people had for decades is diminishing.

\section{References}

Andrusz, G. 2001. Cities: Post-Socialist, in N. J. Smelser, P. B. Baltes (Eds.). International encyclopaedia of the social \& behavioural sciences. Amsterdam: Elsevier.

Appadurai, A. 1986. Theory in anthropology: center and periphery, Comparative Studies in Society and History 28: 356-357. http://dx.doi.org/10.1017/S0010417500013906

Appadurai, A. 2003. Sovereignty without territoriality: notes for a postnational geography', in S. M. Low, D. LawrenceZúñiga (Eds.). The anthropology of place and space: locating culture. Oxford: Blackwell, 337-49.

Beck, U. 2002. The cosmopolitan society and its enemies, Theory Culture and Society 19(1-2): 17-44.

Bittner, R.; Hackenbroich, W.; Vàckler, K. (Eds.). 2006. Transit spaces. Jovis-Verlag.

Blank, D. R. 2004. Fairytale cynicism in the 'Kingdom of Plastic Bags': the powerlessness of place in a Ukrainian border town. Ethnography 5(3): 349-378.

Bourdieu, P. 1984. Distinction: a social critique of the judgement of taste. Translated by R. Nice. Cambridge, MA: Harvard University Press.

Brenner, N.; Theodore, N. 2002. Cities and the geographies of "actually existing neoliberalism, Antipode 34(3): 349-379.

Castells, M. 2002. The Internet galaxy: reflections on the Internet, business, and society. Oxford: Oxford Press.

Crowley, J. 1999. The politics of belonging: some theoretical considerations, in A. Geddes, A. Favell (Eds.). The politics of belonging: migrants and minorities in contemporary Europe. Aldershot: ICCR: Ashgate.

Delanty, G.; Rumford, C. 2005. Rethinking Europe. Social theory and the implications of Europeanization. London/New York: Routledge. 
Dogan, M. 2004. Four hundred giant cities atop the world, International Social Science Journal 56: 347-360.

Foucault, M. 1997. Society must be defended. Lectures at the Collège de France, 1975-1976. Translated by David Macey. Edited by Mauro Bertani and Alessandro Fontana.

Giddens, A. 2000. The third way and its critics. Cambridge: Polity Press.

Glazychev, V. 2000. Glubinnaya Rossiya. Moscow: Novoe Izdatel'stvo.

Griswold, W.; Engelstad, F. 1998. Does the center imagine the periphery? State support and literary regionalism in Norway and the United States, Comparative Social Research 17: $129-75$.

Hammersley, M.; Atkinson, P. 2003. Ethnography: principles in practice. London: Routledge.

Huxley, T. H. 1989. Evolution and ethics. Princeton: Princeton University Press.

Kagansky, V. 2001. Kul'turnyi landshaft i sovetskoe obitaemoe prostranstvo. Mosco:, Novoe Literaturnoe Obozrenie.

Karachurina, L. 2006. Demographicheskaya situatsiya; regional'nye osobennosti, Otechestvennye Sapiski, 5 [online, [cited 15 September 2014]. Available from Internet: http://www. strana-oz.ru/?numid $=32 \&$ article $=1344$

Keil, R. 1994. Global sprawl, urban form after Fordism, Society and Space 12(2): 131-136.

Lefebvre, H. 1991. The production of space. Oxford: Blackwell Publ.

Levy, D.; Sznaider, N. 2006. Forgive and not forget: reconciliation between forgiveness and resentment, in E. Barkan, A. Kam. (Eds.). Taking wrongs seriously: aplogies and reconciliation. Stanford: Stanford University Press, 83-100.

Marvin, S.; May, T. 2003. City futures Views from the centre, City: Analysis of Urban Trends, Culture, Theory, Policy, Action 7(2): 213-225.

Massey, D. B. 1994. Space, place, and gender. Minneapolis: University of Minnesota Press.

Massey, D. 2005. For space. London: Sage.

Massey, D. 2007. Some geographical thoughts on "flesh and stone", City 1(1): 164-166.

Massumi, B. 1997. The political economy of belonging and the logic of relation, in C. Davidson (Ed.). Anybody. Cambridge, MA: MIT Press, 224-238.

Merridale, C. A. 2003. Redesigning history in contemporary Russia, Journal of Contemporary History 38(1): 13-28. http://dx.doi.org/10.1177/0022009403038001961

Milchin, K. 2010. Rossiya: sposob suschestvovaniya, Russkii Reportyer, 39 [online], [cited 12 October 2014]. Available from Internet: http://www.expert.ru/printissues/russian reporter/2010/39/interview_ivanov?esr $=15$

Minca, C. 2006. Giorgio Agamben and the new biopolitical nomos, Geographisca. Annaler Series B Human Geography 88(4): 387-403.

Orehovski, P. 2006. Sposoby zhizni rossiiskoi glubinki: mezhdu stagnatsiei i upadkom, Otechestvennye Sapiski, 5 [online], [cited 15 September 2014]. Available from Internet: http:// www.strana-oz.ru/?numid $=32$ \&article $=1340$

Oswalt, P. (Ed.). 2005. Shrinking cities, Vol. 1: International Research. Hatje Cantz Publishers.

Otechestvennye Zapiski. 2006. Thematic issue "Anatomiya Provitsii.” No. 5 [online], [cited 15 September 2014]. Available from Internet: http://www.strana-oz.ru/?numid= $32 \&$ article $=1330$
Shevchenko, O.; Schukin, Y. 2004. From socialist camp to a global village?: Globalization and the imaginary landscapes of postsocialism, in McCann, L. (Ed.). Russian transformations: challenging the global narrative. London: Routledge Curson, 89-111.

Smith, N. 2002. New globalism, new urbanism: gentrification as global urban strategy, Antipode 34(3): 427-450.

Swyngedouw, E.; Kaïka, M. V. 2003. The making of 'glocal' urban modernities, City 7(1): 5-21.

Taylor, P. J. 2007. Problematizing city-state relations: towards a geohistorical understanding of contemporary globalization, Transactions of the Institute of British Geographers 32(2): 133-150.

Terranova, T. 2007. Futurepublic: on information warfare, bioracism and hegemony as noopolitics, Theory, Culture, Society 24(3): 125-145.

Thrift, N. 2003. With child to see any strange thing: everyday life in the city, in G. Bridge, S. Watson. A companion to the city. Oxford: Blackwell, 398-410.

Thrift, N. 2007. Non-representational theory: space, politics, affect. London: Routledge.

Trubina, E. 2012. Class differences and social mobility amongst college-educated young people in Russia, in S. Salmenniemi (Ed.). Rethinking class in Russia. London: Ashgate.

Turner, B. 2002. Cosmopolitan virtue, globalization and patriotism, Theory, Culture \& Society 191(2): 45-64.

Zamkadyshi. 2010. [Online], [cited 15 September 2014]. Available from Internet: http://www.youtube.com/watch?v=AU8Deasryk

Weir, M. 1996. Central cities' loss of power in state politics, Cityscape: A Journal of Policy Development and Research 2(2): 23-40.

White, A. 2004. Small-town Russia. Postcommunist livelihoods and identities. A portrait of the intelligentsia in Achit, Bednodemyansk and Zubtsov, 1999-2000. London, New York: RoutledgeCurzon.

\section{ELENA TRUBINA}

She is Professor of Social Theory in the Institute of Social and Political Studies at Ural Federal University in Ekaterinburg, Russia. E-mailelena.trubina@gmail.com

Her research addresses a broad set of issues in social theory, including hyperconstruction, mega-events, the intersections between cultural memory and built environment, and the interactions between urban space and subjectivities. She is co-editor (with Michele Rivkin-Fish) of "Dilemmas of Diversity after the Cold War: Analyses of Cultural Differences by United States- and Russia-Based Scholars" (2010) and of "Russian Mass Media and Changing Values" (2010) (with Arja Rosenholm and Kaarle Nordenstreng). Her publications in Russian include Travma: Punkty (2010) (together with Sergey Oushakine) and Gorod v Teorii (City in Theory) (2011) which received numerous reviews in academic and intellectual press and is a best-seller among urban books in Russia. Her current research project examines the relationship between neoliberalism, creativity discourse and the state in several Russian provinces, with a special focus on international events. She is also a part of the team which launched in 2011 the MA programme "Critical urban stidies" at European Humanities University (Vilnius). Her latest publications include:

Trubina E. 2015. Manipulating neoliberal rhetoric: clientelism in the run-up to international summits in Russia. European Urban and Regional Studies 22(2): 128-142. 